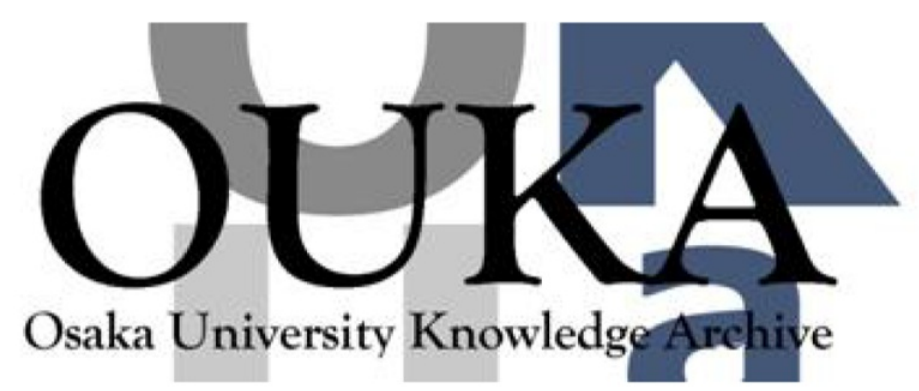

\begin{tabular}{|c|l|}
\hline Title & FREEDOM OF EXPRESSION IN JAPAN \\
\hline Author(s) & Matsui, Shigenori \\
\hline Citation & Osaka University Law Review. 38 p. 13-p. 42 \\
\hline Issue Date & $1991-02$ \\
\hline oaire:version & VoR \\
\hline URL & https://hdl. handle. net/11094/8543 \\
\hline rights & \\
\hline Note & \\
\hline
\end{tabular}

Osaka University Knowledge Archive : OUKA

https://ir. Library. osaka-u. ac. jp/

Osaka University 


\title{
FREEDOM OF EXPRESSION IN JAPAN ${ }^{*}$
}

\author{
Shigenori Matsui*
}

\section{INTRODUCTION}

Freedom of expression is generally recognized as the bulwark of all other freedoms and thus as the essential constituent of democracy. If one examines to what extent freedom of expression is protected, therefore, one would justifiably be able to assess to what extent democracy is actually working in that country. Then what about Japan? Is freedom of expression sufficiently protected in Japan?

The Japanese Constitution of 1946 in its Art. 21 provides:

Freedom of assembly and association as well as speech, press, and all other forms of expression are guaranteed.

No censorship shall be maintained...

Freedom of expression is thus constitutionally guaranteed in Japan.

This freedom was already protected under the Meiji Constitution of 1889 , the first modern Constitution in Japan. But it was only a benevolent grant from the Emperor to his subjects and its protection had to yield to any restrictions imposed by the statutes. Thus freedom of expression was subject to various restrictions under such Acts as the Public Peace Preservation Act, Newspapers Act, or Publications Act. And it was severely oppressed before and during the World War II. Socialist or communist expression was most rigorously curtailed from the beginning but soon all kinds of criticism against the Government came to be similarly curtailed. Especially during the wartime, there was no freedom to criticize the sacred war or even to refrain from actively supporting that war. Since there was no system of judicial review, there was no possibility of judicial relief either.

After the World War II, the General Headquarters (GHQ) of the Supreme Commander for the Allied Powers (SCAP), believing that these restrictions on freedom of expression were greatly responsible for the emergence of extreme militarism in Japan,

* (C) Nov. 29, 1990. All rights reserved. The earlier version of this paper was originally presented as a national report at the XIIIth Congress of the International Academy of Comparative Law held in Montreal, Canada, from August 19 to 25, 1990.

** Associate Professor, Faculty of Law, Osaka University, Japan. 
was so determined that full protection of freedom of expression would be vital to future development of democracy in this country. It thus ordered abolitions of all statutes and regulations restricting these freedoms. And it even ordered immediate release of those detained under these statutes when it found that the Japanese Government had no intent of such release. The protection accorded to freedom of expression by the Japanese Constitution apparently reflects this history.

Everyone would agree, therefore, that freedom of expression is fully guaranteed in Japan at least on the text of the Constitution. But is it sufficiently protected also in its actual operation?

In order to answer this question, this paper will portray major issues concerning freedom of expression in Japan. ${ }^{1}$ And it will attempt to give at least a provisional answer to that question.

\section{THE GENERAL THEORY OF FREEDOM OF EXPRESSION}

\section{1-1. The Constitutional Guarantee}

Even though Art. 21 separately lists freedom of assembly, association, speech and press, there is no doubt that it purports to protect all forms of expression. And it is also evident that the Japanese Constitution which declares the sovereign power of the people restricts legislative acts as well. The Constitution itself made it clear in Art. 98 by stipulating that the Constitution is the supreme law of the land and that any legislative acts contrary to its provision are void and null. Moreover, the Constitution vests the power of judicial review in the judiciary (Art. 81). This means that legislative acts which restrict freedom of expression are subject to judicial review. The Supreme Court thus plays a central role in providing constitutional protection to freedom of expression.

\section{1-2 Limits to Freedom of Expression}

Freedom of expression, even though protected by the Constitution, is not literally absolute. It must be circumscribed for the protection of the public welfare.

The Court has made this clear from the beginning. Thus, already in the Emergency Food Supply Order Case of $1949^{2)}$, the Court said:

1) For more detailed analysis, see L. Beer, Freedom of Expression in Japan: A Study in Comparative Law, Politics, and Society (1984), together with my book review, Matsui, Book Review, 34 Am. J. Com. L. 583 (1986).

2) The judgment of May 18, 1949, Supreme Court, grand bench, Keishu vol. 3, no. 6, at 839. 
Free speech guaranteed by the new Constitution... naturally cannot be arbitrarily curtailed even by statutes. Nevertheless, the public should not abuse fundamental human rights guaranteed to them by the new Constitution. The public rather have responsibility to exercise these rights for the public welfare.... Even free speech guaranteed by the new Constitution should not be exercised by the public in their utter license. It should rather be accommodated to the interest of the public welfare.

From this undeniable limits to freedom of expression, however, the Court all too easily jumped into a conclusion that the restriction on freedom of speech imposed by the Emergency Food Supply Order was constitutional. In this case, the defendant made a speech at the farmers assembly to the effect that farmers had been deceived by the Government and that they should better not sell their rice crops to the Government. Since the delivery of rice crops to the Government was mandated by the Food Control Act and the Emergency Food Supply Order, his speech was regarded as an advocacy of illegal conduct and he was prosecuted. In upholding his conviction, the Court said:

The Food Control Act was enacted under the current poor condition of vital food supply for the purpose of securing its sufficient supply to the general public. In order to accomplish that purpose, an obligation to sell vital food to the Government is imposed by the Order under the provisions of that Act. An advocacy such as this one urging the disobedience of that obligation... goes beyond the mere criticism of the governmental policy and attacks on its failure. It rather undermines the public welfare by advocating a disobedience of important obligation imposed upon the citizen by the statute.

The Court thus concluded that the criminal punishment of advocacy of illegal conduct was constitutional.

The Court here did not inquire seriously what kind of speech the defendant had made and what kind of danger the speech had created. If the speech fell within the prescribed advocacy, under the Court's view, then its criminal punishment would be held constitutional.

The similar attitude can be observed also in the Lady Chatterley's Lover Case. ${ }^{3)}$ In this case, Bin Itoh, a famous novelist, translated and published the D. H. Lawrence's

3) The judgment of March 13, 1957, Supreme Court, grand bench, Keishu vol. 11, no. 3, at 997. 
famous novel, "Lady Chatterley's Lover." He was prosecuted together with his publisher and was charged with a violation of Sec. 175 of the Criminal Law which prohibits the sale or distribution of obscene materials. The Court here again stated:

The Court has made it clear over and over again that fundamental human rights, regardless of whether the possibility of its restriction for the public welfare is stipulated in each provision, cannot be abused by way of Articles 12 and 13. They are subject to restriction for the public welfare and are thus not unlimited... When we apply this general principle to freedom of speech or freedom of expression, such freedom, highly important as it may, can be restricted for the interest of the public welfare.

And here again, the Court concluded without pause that the maintenance of the minimum level of sexual morality was unquestionably in accord with the public welfare and that the prohibition on publication of obscene materials with the criminal punishment was thus constitutional.

Commentators were highly critical of these decisions of the Court. They attacked the Court's unlimited deference toward the judgments of the Diet and its almost total absence of any judicial scrutiny.

In the 1960 s, however, probably partly under the influence of these criticisms, the Court came to employ the interest balancing test in several cases. The most famous was the Hakata Station TV Film Subpoena Case. ${ }^{4)}$ In this case, the district court was deciding whether to indict police officers for using brutal forces against public demonstrators. The court subpoenaed the TV films on the scene of crash between demonstrators and police force which were broadcast on TV. The Court rejected the appeal from the TV stations against the subpoena. To decide the constitutionality of the subpoena, the Court said, it is necessary to balance competing factors. The Court held:

We have to consider on the one hand the nature, manner and seriousness of the crime to be charged, the evidential value of films, and in the end the necessity of these films to accomplish fair criminal trial. Against these we have to balance on the other hand the degree of threat to news-gathering freedom of mass media to be caused by the subpoena, the degree of burden upon the freedom of news-broadcasting and other

4) The decision of Nov. 26, 1969, Supreme Court, grand bench, Keishu vol. 23, no. 11, at 1490. 
various factors. And even when the films are deemed as necessary for use as evidence for criminal trial, the resulting burden upon mass media should be carefully tailored not to exceed the necessity.

In this case, the Court found, the subpoenaed films had the extremely significant evidential value, almost essential, to decide the indictment. On the other hand, they were already broadcast on TV and the only burden upon mass media was the possible threat to future news-gathering activities. Even though such activities should be accorded ample respect in light of the underlying spirit of Art. 21, the Court found, this threat was uncertain and was outweighed by the imperative governmental interest in finding the truth. The subpoena was thus upheld.

Another representative case was the Sarufutsu Case. ${ }^{5)}$ In this case, a postal worker in Sarufutsu city putted up several posters in support of a particular election candidate and distributed many others for sticking. All of this were conducted during his off-duty hours and he did not use any facilities of the office. But he was prosecuted and was charged with a violation of Sec. 102 of the National Public Workers Act which comprehensively prohibits "any political activities" of national public workers. In deciding the constitutionality of the conviction, the Court here again balanced competing interests. The first factor to be considered was governmental interests. The legislative purposes of Sec. 102, securing political neutrality among public workers and maintaining public trust, were apparently legitimate. And the prohibition of political activities capable of undermining these interests, the Court found, bore reasonable relationship to legislative purposes. The second factor was freedom of expression of individual public worker. The prohibition was purported to curtail only conduct, and not personal opinion itself. The restriction on free speech was thus indirect and incidental. The third factor was the balance between governmental interests and burdens upon freedom of speech. The Court then held that the incidental restriction upon free speech was outweighed by the overriding importance of governmental interests. The prohibition of almost all political activities of public workers was thus upheld.

The Court's use of the interest balancing test is certainly preferable to its earlier attitude of simply invoking the talismanic word of public welfare, paying almost total deference toward the judgments of the Diet, thus refusing any meaningful scrutiny of legislative facts. Yet, even in applying the interest balancing test, the Court has never struck down any statutes restricting freedom of expression. While employing that test,

5) The judgment of Nov. 6, 1974, Supreme Court, grand bench, Keishu vol. 28, no. 9, at 393. 
the Court has simply continued to defer to the judgments of the Diet, emphasizing the overriding importance of governmental interest while at the same time undervaluing the degree freedom of expression is restricted.

Commentators argue that freedom of expression occupies the preferred position in the hierarchy of constitutional rights. Under the influence of Professor T.I. Emerson's work, this freedom is believed to be essential for self-realization of individual, finding truth in marketplace of ideas, and functioning of democracy. The judiciary bears, they thus argue, a special responsibility for protecting this freedom. It should not presume the constitutionality of statutes restricting free speech unlike statutes restricting economic freedoms and should rather subject them to strict scrutiny.

Nevertheless, the Court has continued to cling to its approach of paying total deference to the judgments of the Diet while occasionally employing the interest balancing test. No Court decision thus far has ever invalidated any statute restricting freedom of expression. Apparently, in the Court's view, freedom of expression is not different from other freedoms. It is after all not accorded any meaningful constitutional protection from the Court. ${ }^{6)}$

\section{1-3. Analytical Framework}

Leading commentators divide statutory restrictions on freedom of expression into two separate categories: restrictions based on contents (content-based restrictions) and restrictions not based on contents (content neutral restrictions). And they would apply different standards of review. The more stringent standard of review for content-based restrictions and less stringent standard of review for content neutral restrictions. While the Court seems to apply roughly the same deferential review to both categories, it nevertheless tends to employ slightly different standards of review. I would hence follow leading commentators here and consider each category separately.

\section{ANCILLARY DOCTRINES}

The constitutional guarantee of freedom of expression is thought to accompany with it several ancillary doctrines. The first is the prohibition of censorship. The second is the two interrelated doctrines based on the similar concern: the overbreadth

6) The Court has implied that stricter standard of review may be applied to restriction on free speech than to restriction on economic freedom. The judgment of April 30, 1975, Supreme Court, grand bench, Minshu vol. 29, no. 4, at 572. Yet it was a statute restricting economic freedom that was struck down and the Court has never applied such stricter standard of review in reviewing restriction on free speech to invalidate it. 
doctrine and the vagueness doctrine. And the third is the less restrictive alternative (LRA) doctrine.

\section{2-1. The Prohibition of Censorship}

The Constitution explicitly prohibits censorship (Art. 21, Sec. 2). Since the constitutional guarantee of freedom of expression entails the general prohibition of prior restraint, this explicit prohibition of censorship has caused a division of views on the scope of prohibited censorship as well as on the degree of prohibition. The majority view defines censorship broadly as encompassing all forms of prior restraint on expression. Sec. 2, according to this view, simply makes the general prohibition of prior restraint more explicit. The prohibition, however, cannot be absolute. The prohibition of censorship by Sec. 2 thus allows some exceptions. The minority view defines censorship narrowly to include only the traditional type of administrative censorship prior to publication. It holds, however, its prohibition to be absolute. According to this view, Art. 21, Sec. 1 already entails the general prohibition of prior restraint on expression. The significance of Sec. 2 thus lies in absolutely prohibiting such narrowly defined traditional type of administrative censorship.

The Court held in the Custom Bureau Inspection Case ${ }^{7)}$ that the prohibition of censorship was absolute with no exception. It took, however, a view of censorship as provided in Sec. 2 even narrower than the minority view. It defined censorship only to include "one that entails the following elements: it is administered by the administrative authority, its coverage reaches to the content of expressed thoughts and other ideas, its purpose is to prohibit all or part of publication and its characteristic is to review the content comprehensively and generally prior to publication and to prohibit the publication if deemed to be inappropriate." According to this definition, no prior restraint other than the outright censorship by the administrative authority would not fall within prohibited "censorship."

At issue was Sec. 21, Subsec. 1 of the Custom Standard Act which prohibits importation of certain items from foreign countries. Its 3rd clause includes materials which "disturb social morality." Under the Custom Act, every importer has to submit an application for permit prior to importation. When custom officials found during custom inspection the imported material to fall within prohibited items, the custom office informs its decision to the importer, thus precluding the possibility of its importation. One importer challenged this procedure in light of the prohibition of censorship stipulated in Art. 21, Sec. 2. The Court rejected, however, this challenge.

7) The judgment of Dec. 12, 1984, Supreme Court, grand bench, Minshu vol. 38 , no. 12, at 1308. 
The custom inspection, the Court held, did not fall within prohibited censorship because of the following reasons. First, it was not prior restraint since the material involved was already published in foreign countries. Secondly, its purpose was to collect custom, and not to review the content of publication comprehensively and generally. Moreover, the prime job of custom office was not such regulation of the content of publication. And finally there was a room for judicial review. The Court thereby simply ignored the fact that the public is deprived of any opportunity to see foreign publications because of this system.

The Court also held in the Hoppou Journal Case ${ }^{8)}$ that a judicial injunction against publication which was found to be defamatory did not fall within prohibited "censorship" because the injunction was not issued from the administrative authority. The Court allowed such injunction, however, only under certain stringent and clear conditions since it nevertheless constituted prior restraint on expression.

\section{2-2. The Overbreadth Doctrine and Vagueness Doctrine}

The overbreadth doctrine allows the court to invalidate an unconstitutional statute which overbroadly restricts freedom of expression on its face, i.e., without consideration of the specific case before the court. This doctrine is based upon the fear against the chilling effect on free speech which might be caused by such an overbroad statute.

The Court has, however, never applied such overbreadth doctrine. Even though many statutes were challenged as overbroadly infringing free speech, the Court upheld them either by declaring the constitutionality of these restrictions in toto ${ }^{9)}$ or by limiting their coverage. ${ }^{10)}$

Based on the same concern, the vagueness doctrine similarly allows the court to invalidate a vague criminal statute which restricts freedom of expression on its face.

The Court has suggested the possibility that vague criminal statutes restricting free speech could be invalidated for violation of the Constitution. If the statute fails to give sufficient notice to the average citizen as to the precise scope of prohibited conducts, the Court said in the Tokushima City Public Safety Ordinance Case, ${ }^{11)}$ then the statute must fall. Yet the Court here concluded that the condition "to maintain traffic order" attached upon a permit for demonstration by the Ordinance was not unconstitutionally

8) The judgment of June 11, 1986, Supreme Court, grand bench, Minshu vol. 40, no. 4, at 872 .

9) The judgment of Nov. 6, 1974, Supreme Court, grand bench, Keishu vol. 28, no. 9, at 393 (Sarufutsu Case).

10) The judgment of June 22, 1983, Supreme Court, grand bench, Minshu vol. 37, no. 5, at 793 (Prison Inmates Newspaper Censorship Case); the judgment of Dec. 12, 1984, Supreme Court, grand bench, Minshu vol. 38, no. 12, at 1308 (Custom Bureau Inspection Case).

11) The judgment of Sept. 10, 1975, Supreme Court, grand bench, Keishu vol. 29, no. 8, at 489. 
vague. The Court has thus never actually invalidated any statutes by employing this doctrine.

\section{2-3. The Less Restrictive Alternative Doctrine}

The less restrictive alternative doctrine can be understood as a special variety of means analysis applicable when a statute restricting free speech is involved. If there is less restrictive alternative to accomplish intended governmental end, this doctrine allows the court to invalidate the statute.

Commentators are generally in favor of this doctrine. The lower court in the Sarufutsu Case applied this doctrine and invalidated a criminal ban on almost all forms of political activities of public workers. ${ }^{12)}$ Yet the Court, as stated above, upheld such a ban in toto.

\section{CONTENT-BASED RESTRICTIONS ON EXPRESSION}

\section{3-1. General Principles}

When reviewing content-based restrictions on free speech, the Court tend to uphold them if they are necessary and reasonable regulations to accomplish important governmental interests. However, the Court tend to defer to judgments of the Diet and other public authorities. It has thus never subject them to real strict scrutiny.

In contrast, most commentators insist on applying the clear and present danger test or the compelling interest test when reviewing content-based restrictions on free speech. The court, they argue, should not presume their constitutionality but subject them to strict scrutiny.

\section{3-2. Hostility Toward a Particular Viewpoint}

The governmental act which is based upon hostility toward a particular viewpoint should be subject to the most rigorous scrutiny.

Of course, the Government is unlikely to confess its hostility toward a particular viewpoint. Yet one example of this kind of restriction can be found in the Imperial Name and Stamp Counterfeit Case. In this case, a group planned to distribute pamphlets criticizing the Emperor. Since these pamphlets included print of the official Imperial Name and Stamp, the police seized almost all pamphlets for a violation of the

12) The judgment of March 25, 1968, Asahikawa District Court, Kakeishu vol. 10, no. 3, at 293, overruled, the judgment of Nov. 6, 1974, Supreme Court, grand bench, Keishu vol. 28, no. 9, at 393. 
prohibition of the counterfeit of the Imperial Name and Stamp (Criminal Law, Sec. 154). Apparently the group did not have any intent to counterfeit the Imperial Name and Stamp. There was also apparently no danger that the public mistakenly took this print as a true Imperial Name and Stamp. Indeed, the police, upon learning that the group was planning to distribute these pamphlets, first attempted to seize them for thier defamatory nature toward the Emperor. Since it became apparent that the police could not charge criminal defamation, the police came to invoke counterfeit charge to seize all pamphlets before distribution. Without doubt, the police seizure was out of sheer hostility toward the viewpoint expressed in the pamphlets. ${ }^{13)}$

\section{3-3. Advocacy of Illegal Conducts}

Advocacy of illegal conducts are prohibited in wide range of statutes. The prohibited advocacies include:

1. advocacy of overthrow of the Government by violent force (Subversive Activities Prevention Act, Secs. 38, 39, \& 40; Criminal Explosives Control Act, Sec. 4)

2. advocacy of illegal strike (National Public Workers Act, Sec. 110, Cl. 17; Local Public Workers Act, Sec. 61, Cl. 4; Self Defense Force Act, Sec. 119, Subsec. 1, Cls 2, 3 \& Subsec. 2)

3. advocacy of illegal disclosure of governmental secret (National Public Workers Act, Secs. 109, 111; Local Public Workers Act, Sec. 60, Subsecs. 2, 62; Self Defense Force Act, Sec. 118, Subsec. 1)

4. advocacy of tax evasion (National Tax Evasion Control Act, Sec. 22, Subsec. 1; Local Tax Act, Sec. 21, Subsec. 1)

The Court construed the word "advocacy" as used in Local Tax Act, Sec. 21, as act "intentionally giving impetus to others by documents, pictures or conducts with such force as to bring about decision to accomplish these prohibited conducts or to prompt the decision already made. ${ }^{14)}$ And the Court has adopted the same definition with respect to word "advocacy" or "incitement" as used in other statutes.

The leading case with respect to the prohibition of advocacy of illegal conducts is

13) The district court thus held the seizure unconstitutional. The decision of March 5, 1985, Osaka District Court., Hanrei Times vol. 556, at 217. Yet, the tort action against the Government for this allegedly unconstitutional seizure was ultimately rejected by the Court. The judgment of Dec. 13, 1990, Ist petty bench, Asahishinbun Dec. 14, 1990.

14) The judgment of Feb. 21, 1962, Supreme Court, grand bench, Keishu vol. 16, no. 2, at 107. 
the above-mentioned Emergency Food Supply Order Case. ${ }^{15)}$ In this case, the Court upheld the criminal punishment of a defendant who made advocacy simply deferring to the judgment of the Diet. According to the Court's holding, if the speech fell within prescribed advocacy, it then did not matter whether the speech was direct incitement or indirect or abstract advocacy of doctrine. Nor it mattered what danger the speech had created or whether the danger was imminent. Indeed, the Court here did not inquire seriously what the defendant had exactly stated and what danger the defendant's statement had created.

Commentators have been thus very critical of the Court's stance. They rather insist on applying the clear and present danger test or the Brandenburg test ${ }^{16)}$ enunciated by the U.S. Supreme Court. Nevertheless, the Court has affirmed its earlier position and has upheld all restrictions on advocacy of illegal conducts. ${ }^{17)}$ In the most recent case concerning criminal prosecution under the Subversive Activities Prevention Act, for instance, the Court quite summarily rejected the argument that the Government could not prohibit subversive speech unless there was clear and present danger. In this case, several leaders of the left-wing radicals urged before their members to "occupy the Metropolitan government" and to "storm the Prime Minister's House." They were prosecuted for their advocacy of subversive conducts for political motivation. The Court, in upholding their conviction, held that such advocacy, being capable of producing grave threats to social safety, was incompatible with the public welfare and was thus unworthy of constitutional protection. ${ }^{18)}$

\section{3-4. Election Campaign}

Political speech is believed to occupy the central place among protected expression. Nevertheless, political speech is most rigorously curtailed in Japan.

Thus the Public Offices Election Act sets up limited election campaign period (Sec.

15) The judgment of May 18, 1949, Supreme Court, grand bench, Keishu vol. 3, no. 6, at 839.

16) Brandenburg v. Ohio, 395 U.S. 444 (1969).

17) The judgment of Jan. 9, 1952, Supreme Court, grand bench, Keishu vol. 6, no. 1, at 4; the judgment of Aug. 29, 1952, Supreme Court, 2nd petty bench, Keishu vol. 6, no. 8, at 1053; the judgment of April 27, 1954, Supreme Court, 3rd petty bench, Keishu vol. 8, no. 4, at 555; the judgment of May 20, 1954, Supreme Court, lst petty bench, Keishu vol. 8, no. 5, at 692; the judgment of Nov. 30, 1955, Supreme Court, grand bench, Keishu vol. 9 , no. 12, at 2545; the judgment of Feb. 21, 1962, Supreme Court, grand bench, Keishu vol. 16, no. 2, at 107; the judgment of April 25, 1973, Supreme Court, grand bench, Keishu vol. 27, no. 4, at 547; the judgment of May 21, 1976, Supreme Court, grand bench, Keishu vol. 30, no. 5, at 1178. The Court also even upheld the constitutionality of criminal punishment of attempt to advocacy. The judgment of Dec. 18, 1989, Supreme Court, 1st petty bench, Hanrei Times vol. 717, at 46.

18) The judgment of Sep. 28, 1990, Supreme Court, 2d petty bench, Asahisinbun Sept. 29, 1990. 
129) and prohibits election campaign before that period (Sec. 239). It also prohibits door-to-door canvassing (Sec. 138) and solicitation for signature (Sec. 138-2). It places almost total ban on distribution of pamphlets (Sec. 142) as well as on posting of written documents (Sec. 143). Moreover it places severe limits on public meetings and gatherings (Secs. 161-66). Because of these restrictions, the almost only permissible method of election campaign in Japan is limited to repeatedly announcing the names of candidates on sound-trucks.

These restrictions have been under fire from commentators and general public. Yet the Court has consistently upheld them. In upholding the limitation of election campaign to designated campaign period, for instance, the Court said: ${ }^{19)}$

If election campaign for public candidates were constantly permitted, improper or unnecessary competitions might be resulted, thus creating dangers that fairness of election might be undermined by the occurrences of illegal conducts because of the difficulty of regulations. Or wanton spending and campaign work might cause imbalance among candidates because of their unequal spending capacities, thus bringing about corruptions of election. In order to prevent these dangers and to secure fairness of election, it is therefore essential to limit election campaign to a relatively short period, to designate the fixed starting date, and to let every candidate compete in campaigning under the same conditions as possible. Sec. 129 of the Public Offices Election Act was purported to meet that demand and provided that election campaign must be from the date of candidacy registration to the date before the voting day. Since securing fairness in election comports with the public welfare, such limitation on election campaign to designated period and prohibition of campaign prior to that period can be said as permissible, necessary and reasonable restrictions on freedom of expression guaranteed by the Constitution...

The Court has never explained, however, of what "improper or unnecessary competitions" might be resulted nor why the Government was allowed to make sure every candidate to compete in substantially equal spending capacity. It has also never explained of why limitation on campaign period was essential to accomplish compelling governmental interests, if any.

Door-to-door canvassing is the most typical and usual method of election campaign

19) The judgment of April 23, 1969, Supreme Court, grand bench, Keishu vol. 23, no.4, at 235. 
in Western nations. Yet it was prohibited when the universal suffrage was first acknowledged in this country. This prohibition survived the constitutional change and was introduced into the Public Offices Election Act. And the Court showed its willingness to uphold this kind of prohibition against the constitutional attack already in $1950 .^{20)}$ Noting that "door-to-door canvassing entails various problems," the Court hastened to conclude:

Art. 21 of the Constitution does not guarantee unlimited freedom of speech but rather naturally admits the possibility of reasonable restrictions as to time, place, and manner of speech for the public welfare. Incidental restriction on free speech resulting from a ban on door-to-door canvassing in order to secure fairness of election... thus does not run counter to the Constitution.

The Court here again did not specify what kind of problems door-to-door canvassing might bring about and why absolute ban was essential to prevent whatever problems it may bring about. Several justifications have been offered by some commentators. The ban, it has been argued, can be justified primarily because it is necessary to prevent illegal fixing and to protect residents from unconsented visitors. These governmental interests are undeniably legitimate and important. But it is still doubtful whether total ban on door-to-door canvassing is essential to secure these governmental interests. Nevertheless, the Court has affirmed this holding ever since despite strong academic and popular criticism and despite some lower court holdings contrary to it. ${ }^{21}$.

The Court also upheld the almost total ban on distribution of pamphlets. ${ }^{22)}$ Sec. 146, the Court held, was enacted because

unlimited distribution or posting of written documents as to election might result in improper competition in election campaign, consequently creating dangers that free and fair election might be hindered and its

20) The judgment of Sep. 27, 1950, Supreme Court, grand bench, Keishu vol. 4, no. 9, at 1799.

21) The judgment of Nov. 21, 1967, Supreme Court, 3rd petty bench, Keishu vol. 21, no.9, at 1245; the judgment of April 23, 1969, Supreme Court, grand bench, Keishu vol. 23, no. 4, at 235; the judgment of June 15, 1981, Supreme Court, 2nd petty bench, Keishu vol. 35, no. 4, at 205; the judgment of July 21, 1981, Supreme Court, 3rd petty bench, Keishu vol. 35, no. 5, at 568; the judgment of March 23, 1982, Supreme Court, 3rd petty bench, Keishu vol. 36, no. 3, at 339; the judgment of Nov. 10, 1983, Supreme Court, 1st petty bench, Keishu vol. 37, no. 9, at 1368; the judgment of Jan. 20,1984, Supreme Court, 2nd petty bench, Keishu vol. 38, no. 1, at 1; the judgment of Feb. 21, 1984, Supreme Court, 3rd petty bench, Keishu vol. 38, no. 3, at 387.

22) The judgment of March 30, 1955, Supreme Court, grand bench, Keishu vol. 9, no. 3, at 635. 
fairness might become hardly maintainable. That provision therefore placed certain limitations on distribution and posting of written documents during the election campaign period in order to prevent such dangers. This degree of limitation could be then viewed as a necessary and reasonable restriction for the public welfare permitted under the Constitution.

The Court here again never explained of what kind of "improper competition" could be resulted from free distribution of pamphlets nor what kind of danger to free and fair election could be created. Nor it did specify to what degree the danger was imminent. Nor it ever explained why almost total ban on distribution and posting of written documents was essential to prevent these dangers. The Court has nevertheless affirmed this holding since then. ${ }^{23)}$

\section{3-5. Defamation}

Defamatory speech, either oral or written, is subject to criminal as well as civil sanctions.

Sec. 230 of the Criminal Law punishes those who made defamatory speech toward others by pointing out facts in public. It punishes every defendant who made defamatory speech regardless of whether it is false or true. ${ }^{24)}$ This provision was originally adopted into the Criminal Law while the Meiji Constitution was in effect. At that time, when the defendant made defamatory speech, there was no way to claim immunity.

When the Japanese Constitution was adopted, many thought this criminal defamation provision unconstitutionally restricted protected freedom. The Criminal Law was thus amended and new Sec. 230-2 was added. The Subsec. 1 of Sec. 230-2 thus declares that a defendant who made defamatory speech as to matters of public interest for the sole purpose of advancing public interest is immune from punishment if he or she proves that speech was true. And Subsec. 2 irrebuttably presumes that a speech was concerned with the matter of public interest if it is issued upon unprosecuted criminal suspect. And Subsec. 3 provides that the defendant who made defamatory

23) The judgment of April 6, 1955, Supreme Court, grand bench, Keishu vol. 9, no. 4, at 819; judgment of Nov. 18, 1964, Supreme Court, grand bench, Keishu vol. 18, no. 7, at 561; the judgment of April 23, 1969, Supreme Court, grand bench, Keishu vol. 23, no. 4, at 235; the judgment of March 23, 1982, Supreme Court, 3rd petty bench, Keishu vol. 36 , no. 3, at 339 .

24) If one made defamatory speech toward others without pointing out facts in public, he may be punished for vilification. The Criminal Law, Sec. 231. Yet the criminal prosecution under Sec. 231 is quite rare. 
speech as to public officials or election candidates for public offices is immune from punishment if he or she could only show that his or her speech was true.

Sec. 230 of the Criminal Law, thus amended, was upheld by the Court. ${ }^{25)}$ " Article 21 of the Constitution," said the Court, "does not guarantee unlimited freedom of speech.... It is an abuse of free speech to defame others. Defamatory speech thus does not fall within constitutionally protected freedom of speech." And the Court has affirmed this holding thereafter. ${ }^{26)}$

Even though the Constitution does not have a provision explicitly protecting reputation of an individual, no one doubts the permissibility for the Diet to protect it by restricting defamatory speech. Yet, Sec. 230-2 on its face still punishes defendant who made defamatory speech as to matters of public interest for the sole purpose of advancing public interest if he or she fails to prove that his or her speech was true. The Court had thus first denied immunity to such defendant. ${ }^{27)}$ Defense of truth is important. But to require a defendant to prove his or her speech to be true is very demanding and it often induces self-censorship. Recognizing this hardship, the Court reversed its previous decision and came to hold:

Sec. 230-2 of the Criminal Law attempts to accommodate the necessity of protecting reputation of individual as a person and protection of free speech guaranteed by Art. 21 of the Constitution. In light of this attempted accommodation and balance between two interests, it is proper to construe Sec. 230-2 of the Criminal Law as immunizing defendant who made defamatory speech from punishment for want of criminal intent, if the defendant made speech out of mistaken belief that his or her speech was true and if there was probable ground for his or her mistaken belief based upon sure information and sources even when he or she could not prove that his or her speech was true.

The Court thus expanded the protection accorded to defamatory speech. ${ }^{28)}$

Commentators are generally in favor of this expansion of protection. The focus is then placed upon the definition of "matters of public interest." The Court held in the Monthly Pen Case ${ }^{29)}$ that "matters of public interest" should be "defined objectively

25) The judgment of April 10, 1958, Supreme Court, 1st petty bench, Keishu vol. 12, no. 5, at 830.

26) The judgment of April 16, 1981, Supreme Court, 1st petty bench, Keishu vol. 35, no. 3, at 84 .

27) The judgment of May 7, 1959, Supreme Court, 1st petty bench, Keishu vol, 13, no. 5, at 641.

28) The judgment of June 25, 1969, Supreme Court, grand bench, Keishu vol. 23, no. 7, at 975.

29) The judgment of April 16, 1981, Supreme Court, 1st petty bench, Keishu vol. 35, no. 3, at 84 . 
in light of the content and nature of facts pointed out themselves." The method of expression or degree of investigation, it thus held, should not influence upon this decision. In this case, the magazine "Monthly Pen" reported a womanizing scandal of Daisaku Ikeda, the President of the Souka-Gakkai, as a part of continuing criticism against the Souka-Gakkai. The Souka-Gakkai is a very influential religious organization and has a strong connection with the Komei Party, third largest party in the Diet. Even though the reported facts concerned with private life of an individual, the Court thus held that this report fell within "matters of public interest."

Those who made defamatory speech toward others are also subject to civil sanction. The Civil Law allows people to file a tort action to recover damages against defamation (Secs. $709 \& 710)^{30)}$ or to seek other remedies to restore damaged reputation (Sec. 723). ${ }^{31)}$ Unlike the Criminal Law, the Civil Law does not contain any provision specifying the conditions for damage action or conditions for the defendant to claim immunity. Nevertheless, almost the same doctrine has developed. And even though there is no provision in civil tort action comparable to Sec. 230-2 of the Criminal Law, the Court has afforded similar immunity to the civil defendant as well. ${ }^{32}$ )

\section{3-6. Commercial Speech}

Commercial speech is restricted in various statutes. The purposes of these restrictions could be divided into two categories: protection of consumers and protection of

30) The Civil Law does not allow punitive damages. The amount of damage usually awarded to defamation plaintiff is less than $\$ 10,000$, mostly $\$ 1.000$ to $\$ 2.000$. Many thus argue that damage award is too small to compensate the loss.

31) The remedy most often used is a forced publication of apology. Even though the Civil Law does not mention about the injunctive relief, the Court held that the plaintiff could also seek injunctive relief. The judgment of June 11, 1986, Supreme Court, grand bench, Minshu vol 40, no. 4, at 872 (the Hoppou Journal case).

32) The judgment of June 23, 1966, Supreme Court, 1st petty bench, Minshu vol. 20, no. 5, at 1118. See also the judgment of April 24, 1987, Supreme Court, 2nd petty bench, Minshu vol. 41, no. 3, at 490 .

There are two significant differences between criminal defamation law and civil defamation law. First, the criminal intent is necessary in the former, while negligence is sufficient in the latter. And secondly, the defendant could be liable only when he or she pointed out the facts in public in the former, while the defendant could be held liable for his or her defamatory opinion in the latter. In a recent case, however, the Court accepted the "fair comment" privilege. The judgment of Dec. 21, 1989, Supreme Court, 1st petty bench, Minshu vol. 43, no. 12, at 2252. In this case, the defendant distributed handbills criticizing the conducts of public school teachers who had refused to comply with the school principals' order to change the assessment standard for evaluation sheets of students and characterized these teachers as "harmful and incompetent teachers." Since the facts depicted in the handbills were substantially true, the Court accepted the defendant's claim that this was fair comment on matters of public concern with the purpose of promoting public interest and was immune from civil liability. The Court ordered the defendant, however, to pay damages for emotional distress caused by listing the names, addresses, and phone-numbers of these teachers on the handbills, thus inviting threats and intimidations to them. 
free and fair competition. And the types of these restrictions could be divided into following four categories:

1. prohibition of false advertisement (Medical Treatment Act, Sec. 69, Subsec. 6, Sec. 71, Subsec. 5; Pharmaceutical Act, Sec. 66, Subsec. 1; Food Safety Act, Sec. 12; Travel Agency Act, Sec. 12-8)

2. prohibition of deceptive, misleading, or exaggerated advertisement (Pharmaceutical Act, Sec. 66, Subsecs. 1 \& 2; Food Safety Act, Sec. 12) 3. prohibition of advertisement of illegal conducts (Prostitution Prevention Act, Sec. 5, Subsec. 3, Sec. 6, Subsec. 3)

4. other prohibitions (Medical Treatment Act, Sec. 69, Subsecs. 1 \& 3, Sec. 71, Subsecs. $1 \& 3$ )

These restrictions are unique to commercial speech. ${ }^{33)}$

The Court gave almost no protection to commercial speech. The leading case in this regard is a case involving criminal prosecution under Sec. 7 of the Massagists, Acupuncturists, Moxibustionists, and Judo Rehabilitationists Act, which limited permissible subjects of advertisement to name, address and other listed information and specifically prohibited advertisement of ability or experience. ${ }^{34)}$ The defendant, a moxibustionist, distributed handbills which described possible effect of his service and was charged with a violation of Sec. 7 . The Court upheld the conviction. This ban was placed, the Court held,

because the Diet feared that permitting unlimited advertisement might possibly bring about false or exaggerated advertisement in attempt to attract customers, thus creating dangers that the general public, being confused, might consequently miss the opportunity to receive timely and adequate medical treatment. Prohibiting advertisement except on specified subjects in order to prevent these dangers in advance must be allowed as a necessary means to maintain the public welfare from the standpoint of protecting public health and safety.

33) In addition to these statutory restrictions, there is a code of comprehensive self-imposed restriction in advertisement industry (Commercial Ethic Code) as well as code of self-imposed restriction on advertisement in each industry (like newspaper, broadcasting, or magazine publishing industry).

34) The judgment of Feb. 15, 1961, Supreme Court, grand bench, Keishu vol. 15, no. 2, at 347. 
Commercial speech can be restricted, in short, if the Diet found it capable of bringing about some kind of danger to the public health and safety.

Commentators are divided. Some contend that pure commercial speech is to be seen as economic activity unprotected by Art. 21. Many contend, however, that even pure commercial speech should be protected under Art. 21 for it serves important social function of providing useful information to consumers. The degree of protection to be accorded to commercial speech, they nevertheless argue, should not necessarily be the same as that accorded to political speech. Since commercial speech has less significant speech interest or it is located not in the center of the constitutional protection, they continue, it is enough to accord less constitutional protection. The prevailing view thus upholds restrictions on commercial speech if the speech is false, misleading or exaggerated, if it involves advocacy of illegal conduct, or if restriction is otherwise necessary to accomplish important governmental interests.

\section{3-7. Obscenity}

Sale as well as distribution of "obscene" materials are prohibited by Sec. 175 of the Criminal Law.

As stated above, the Court upheld the constitutionality of Sec. 175 in the Lady Chatterley's Lover Case. ${ }^{35)}$ The criminal prohibition on sale and distribution of obscene materials, said the Court, was necessary to maintain the public welfare, i. e., to maintain the "minimum level of sexual morality." Moreover, in reaching this conclusion, the Court opined that one essential characteristic of human-being is to sense shame. Aversion to open sexual conduct, according to the Court, is just one manifestation of this sense of shame. The Court admitted the possibility that the public attitude toward obscenity might change. It nevertheless held that this aversion to open sexual conduct was beyond change. The Court then went on to declare:

Even if the ethical sense of vast majority of people were numbed and even if they would refuse to admit truly obscene material to be obscene, the court must follow the norm of social common sense, that is, consciousness of men of decent morality, and guard the society from moral denigration. For the law and court must not approve the changing social reality but rather play a clinical role against moral denigration by taking critical stance to it.

35) The judgment of March 13, 1957, Supreme Court, grand bench, Keishu vol. 11, no. 3, at 997.

36) The judgment of Oct. 15, 1969, Supreme Court, grand bench. Keishu vol. 23, no. 10, at 1239. 
This holding was affirmed thereafter in a case involving the "In Praise of Vice" written by Marques de Sade ${ }^{36)}$ and has been followed since then. ${ }^{37)}$

According to the Court, "obscenity" is an expression which "wantonly excites or stimulates sexual desire, offends normal sense of the ordinary people to feel shame for sexual conduct, and runs counter to decent sexual morality."38) Whether a particular material is or is not obscene should be decided in light of the document taken as a whole. And even if the material has artistic or literal value, it can be obscene. The Court thus rejected argument that highly artistic or literal expression could not be prohibited as obscene or argument that the court should balance artistic or literal value of the material against social interest in preventing obscenity before upholding conviction. ${ }^{39)}$ The Court also rejected the argument that the definition of obscenity as used in Sec. 175 was unconstitutionally vague. ${ }^{40)}$

This fundamental framework has not been changed a bit. Yet the Court recently showed some signs to narrow the scope of obscenity. In a recent case, ${ }^{41)}$ the Court held as follows:

In deciding the obscene nature of a document, it is necessary to consider many factors, including whether the document, taken as a whole, can be generally said to appeal to prurient interest of the readers in light of the degree and method of explicit and detailed sexual depiction and description involved in that document, the ratio of that depiction and description against the document as a whole, the relationship between that depiction and description and the thought expressed in that document, the structure and flow of the document, and the degree that sexual stimulus was reduced by artistic or philosophical nature of that document. The court should decide whether it "wantonly excites or stimulates sexual desire,

37) The judgment of Nov. 28, 1980, Supreme Court, 2nd petty bench, Keishu vol. 34, no. 6, at 433; the judgment of March 8, 1983, Supreme Court, 3rd petty bench, Keishu vol. 37, no. 2, at 15; the judgment of Oct. 27, 1983, Supreme Court, Ist petty bench, Keishu vol. 37, no. 8, at 1294. See also the judgment of Dec. 12, 1984, Supreme Court, grand bench, Minshu vol. 38 , no. 12 , at 1308.

38) The judgment of March 13, 1957, Supreme Court, grand bench, Keishu vol. 11, no. 3, at 997.

39) The judgment of Oct. 15, 1969, Supreme Court, grand bench, Keishu vol. 23, no. 10, at 1239.

40) The judgment of Nov. 28, 1980, Supreme Court, 2nd petty bench, Keishu vol. 34, no. 6, at 433; the judgment of March 8, 1983, Supreme Court, 3rd petty bench, Keishu vol. 37, no. 2, at 15.

41) The judgment of Nov. 28, 1980, Supreme Court, 2 nd petty bench, Keishu vol. 34, no. 6, at 433. 
offends normal sense of the ordinary people to feel shame for sexual conduct, and runs counter to decent sexual morality" in light of the contemporary good social common sense by taking all these factors in consideration.

Although the Court upheld the conviction in this case, this Court holding prompted some lower courts to acquit the defendants prosecuted under Sec. 175 by denying the obscene nature of the documents charged. Yet the Court has still steadily refused to limit the prohibition to so-called hard-core pornography. ${ }^{42)}$

Commentators are highly fragmented. Some support the Court's holding but some contend that, while the prohibition of distribution of obscene materials is constitutional, Sec. 175 should be narrowly construed to prohibit only hard-core pornography. Another commentators insist that Sec. 175 is unconstitutional since there is no reason to prohibit obscenity. The Government should not be allowed, they claim, to prohibit expressive activity in order to maintain sexual morality. There are also some who argue for its unconstitutionality because of its overbreadth and vagueness.

\section{CONTENT NEUTRAL RESTRICTIONS ON EXPRESSION}

\section{4-1. General Principle}

When time, place, and manner of expression is restricted, the Court showed its willingness to uphold restrictions so far as they are reasonable. Moreover, in deciding the reasonableness of these content-neutral regulations, the Court appears to give slightly more deference to the judgments of the Diet and other public authorities than with respect to content-based restrictions.

In contrast, most commentators insist that the Court should subject content-neutral restrictions to more demanding scrutiny. The review does not have to be as stringent as one to be applied to content-based restriction. Yet the court should, they insist, at least employ the less restrictive alternative doctrine.

42) The judgment of March 8, 1983, Supreme Court, 3rd petty bench, Keishu vol. 37, no. 2, at 15. Besides Sec. 175 of the Criminal Law, many local governments have so-called "youth protection ordinances" restricting such materials which are "sexually stimulating or encouraging extreme brutality" and are capable of interfering with sound fostering of the youths. These materials are not "obscene" as defined by the Court. The Court upheld such ordinance, however, simply by saying that such an ordinance was a reasonable measure to prevent widely acknowledged social evils. The judgment of Sept. 19, 1989, Supreme Court, 3rd petty bench, Keishu vol. 43, no. 8 , at 785 . 


\section{4-2. Anti-Noise Regulations}

Even though some municipalities have anti-noise regulations on street expression, there is no comprehensive statute regulating the noise level of expression. ${ }^{43}$ ) There is no case law concerning the constitutionality of such anti-noise regulations.

\section{4-3. Restrictions on Handbills}

Distribution of handbills or pamphlets is free on the public street. Yet in some facilities, such as city hall or railroad station, such an activity is prohibited altogether or severely regulated.

The Court upheld a ban on distribution of handbills on the premise of private railroad station under Sec. 35 of the Railroad Business Act. ${ }^{44)}$ Such a ban, it held, was necessary and reasonable restriction on free speech in order to protect the property right or management authority of railroad companies.

\section{4-4. Restrictions on Posters and Billboards}

Posters and billboards are strictly regulated.

The Billboard Act authorizes each municipality to adopt necessary regulations on billboards and most municipalities have thus adopted Billboard Ordinances, which prohibit posters and billboards on public facilities, such as electricity polls, street trees, or postal deposits.

The Court upheid such regulations against the constitutional attack. In the Osaka City Billboard Ordinance Case, ${ }^{45)}$ the Court held that the maintenance of beautiful and enjoyable surroundings of the city fully comported with the public welfare. "This degree of regulation," it thus concluded, "can be said as a necessary and reasonable restriction on freedom of expression permissible in order to maintain the public welfare."46)

Sticking posters on private property without getting consent is also prohibited by Sec. 1, Cl. 33 of the Misdemeanor Act. The Court upheld this restriction as a necessary and reasonable one in order to protect private property, even though the private property involved in this case was electricity polls owned by the electric power company, semi-public entity. ${ }^{47)}$

43) Cf. the Act to Preserve Serenity in the Vicinities of the Diet Building and the Foreign Embassy Buildings of 1988 .

44) The judgment of Dec. 18, 1984, Supreme Court, 3rd petty bench, Keishu vol. 38, no. 12, at 3026,

45) The judgment of Dec. 18, 1968, Supreme Court, grand bench, Keishu vol. 22, no. 13, at 1549.

46) See also judgment of March 3, 1987, Supreme Court, 3rd petty bench, Keishu vol, 41, no. 2, at 15.

47) The judgment of June 17, 1970, Supreme Court, grand bench, Keishu vol. 24, no. 6, at 280. 


\section{PUBLIC MEETINGS AND DEMONSTRATIONS}

\section{5-1. Public Meetings and Demonstrations}

Art. 21 explicitly protects "freedom of assembly." The right to hold public meetings is thus unquestionably protected. And even though the Constitution does not refer to the right to conduct mass demonstration, there is no doubt that it should also be protected.

However, even these rights must yield to restrictions for the public welfare. The right to conduct mass demonstration is hence subject to restrictions by the Public Safety Ordinance of each municipality and by the Road Traffic Act. And the right to hold public meetings at parks is subject to restriction by the park authority.

\section{5-2. The Public Safety Ordinances}

Mass demonstrations were free after the World War II. When demonstrations came to threaten the public safety, however, the General Headquarters of the Supreme Commander for the Allied Powers prompted the local government to regulate such demonstrations. Many municipalities responded by enacting so-called Public Safety Ordinances. Precise language and scheme vary but they generally require the advance notification or application for permit to conduct demonstration on public streets. The permit is usually given if planned demonstration satisfies certain conditions listed in the Ordinances. On the other hand, the permit is usually denied if planned demonstration is likely to threaten the public safety. Demonstration may be permitted under modified plan or some conditions may be attached on permit. Participants of demonstration without permit or demonstration which violated attached conditions are punished with criminal penalty.

In a 1954 case involving the Niigata Prefecture Public Safety Ordinance, the Court first confronted this issue. ${ }^{48)}$ The Court held mere notification requirement was permissible. Since public demonstration is constitutionally protected, it would be thus unconstitutional to enact general licensing system. The Court intimated, however, that it was constitutional to require permit in advance with respect to particular place or manner under reasonable and clear standards. And it was also constitutional to refuse permit when the clear and imminent danger to the public safety was anticipated. The Court, while upholding the constitutionality of the Public Safety Ordinance, thus significantly limited its reach.

When the Court reviewed the constitutionality of the Tokyo Metropolitan Public

48) The judgment of Nov. 24, 1954, Supreme Court, grand bench, Keishu vol. 8, no. 11, at 1866. 
Safety Ordinance in 1960 , it changed its view. ${ }^{49)}$ Even though public demonstration is constitutionally protected, the Court insisted, it has a potential to become a mob instantly. It is thus constitutional for the local government to enact necessary and minimum measure to secure law and order. And the Court upheld the general permit requirement of the Ordinance despite its 1954 holding. Since the Ordinance involved obliged the police authority to give permit unless a demonstration is apparently likely to cause direct danger to the public safety, the Court thought, the regulation could be deemed constitutional. This holding came close to saying that mass demonstration was nothing but riot and could be restricted in order to prevent whatever possible dangers to the public safety it might bring about.

Some lower courts responded, however, to this Court decision by acquitting some demonstration participants while admitting the constitutionality of the Ordinances. They held that participants of demonstration without permit or demonstration which violated attached conditions should still be immune from punishment if demonstration did cause no specific threat or only negligible threat to the public safety undeserving of criminal punishment. And some lower court even refused to follow the Court precedent and held the Ordinance unconstitutional.

The Court nevertheless reversed all these lower court decisions. The Court held that it was constitutional to punish participants, though there were no specific threat or only negligible threat to the public safety. ${ }^{50)}$ The Court further held in the Tokushima City Public Safety Ordinance Case ${ }^{51)}$ that the condition attached on the permit to "maintain the traffic order" was not unconstitutionally vague.

Commentators are generally critical of the Court. Most commentators insist that demonstration is the unique form of expression easily resorted to by ordinary people. It should not be hence prohibited, they conclude, unless there is a clear and present danger to the public safety.

\section{5-3. Demonstration and Traffic Safety}

Demonstration is also subject to regulation under the Road Traffic Act for securing the traffic safety.

The Court upheld such a regulation in the Enterprise Protest Demonstration Case. ${ }^{52)}$ Sec. 77, Subsec. 1 of the Road Traffic Act, together with the order of the Prefecture,

49) The judgment of July 20, 1960, Supreme Court, grand bench, Keishu vol. 14, no. 9, at 1243.

50) The judgment of Oct. 24, 1975, Supreme Court, 2nd petty bench, Keishu vol. 29, no. 9, at 777; the judgment of Oct. 24, 1975, Supreme Court, 2nd petty bench, Keishu vol. 29, no. 9, at 860.

51) The judgment of Sept. 10, 1975, Supreme Court, grand bench, Keishu vol. 29, vol. 8, at 489.

52) The judgment of Nov. 16, 1982, Supreme Court, 3rd petty bench, Keishu vol. 36, no. 11, at 908. 
required demonstrators to acquire advance permit. The Court rejected the constitutional attack against this general permit requirement. It held, however, that the police could not refuse permit unless demonstration was likely to impair general traffic significantly and such an impairment could not be prevented by attaching conditions on the permit.

\section{5-4. Public Meetings at Parks and Other Public Forum}

The right to hold public meetings at parks is subject to restriction by the park authority. Some park authorities thus require an advance permit. They then refuse to grant the permit if the planned meeting would be likely to impair the park or otherwise interfere with the management of the park by the authority.

The typical case was presented in the May Day Meeting at the Exterior Garden of the Emperor's Palace Case. ${ }^{53)}$ The union planned to hold a May Day meeting at the Exterior Garden of the Emperor's Palace and applied for a permit. Yet the Welfare Minister refused to grant a permit because the meeting might cause damages to the Garden. The union filed a suit attacking the refusal, insisting that similar May Day meetings were previously permitted and that there was no clear and present danger for causing serious damages to the Garden.

The Court dismissed the suit for being moot because the planned date of meeting had passed. Yet the Court went on to register its opinion utterly in dicta on the merit and upheld the constitutionality of the refusal. It was constitutional for the Welfare Minister, the Court intimated, to refuse the permit when he thought the planned meeting would cause serious damages to the Garden and prevent other general public to use that Garden for its most natural use.

The same rule would apply to other public forum such as city hall, public theater, or public concert hall as well. Yet the manager of the public facility should not be allowed to refuse the public use because of the content of the expression. And the manager should not be allow to refuse the public use based upon a fear of disturbances to be caused by the third party. This situation is often presented when the Japan Teachers Union plans to hold meetings because the right-wing hecklers always come to interfer with the meetings with loud sound-trucks, yelling and cursing the Uion, and sometimes cause bodily injuries and property damages to Union members and surrounding houses and stores. The managers of the public facility often responded to this by revoking the permit for use when they learned that the Japan Teachers Union was involved. The number of lower courts refused, however, to let the revocation to

53) The judgment of Dec. 23, 1953, Supreme Court, grand bench, Keishu vol. 7, no. 13, at 1561. 
stand, because the revocation was held to be unconstitutional violations of the right of freedom of expression. ${ }^{54}$

\section{THE RIGHT TO RECEIVE AND GATHER INFORMATION}

\section{6-1. The Right to Receive and Gather Information}

Even though Art. 21 only mentions to expression, it is widely believed that it also protects the right to receive information as well as the right to gather information. For the right of expression is meaningless if one cannot receive or gather information.

The Court also acknowledged in the Prison Inmates Newspaper Censorship Case, to be discussed below, that the people have a right to read newspaper. Moreover, as discussed below, the Court has accorded some constitutional protection to news-gathering activities.

\section{6-2. Restrictions on the Right to Receive Information}

In ordinary situations, one is free to receive information. Yet, in certain situations, the people's right to receive information may be curtailed.

One such situation is presented in the Prison Inmates Newspaper Censorship Case. ${ }^{55)}$ The Prison Act allows the inmates to read books and newspapers but it authorizes the prison authority to censor and ban or delete whatever portions the authority judges to be inappropriate. The Court acknowledged that the prison inmates had a right to read newspaper protected by Art. 13 and Art. 21. It thus narrowly construed the Act to allow ban or deletion only "when there is considerable likelihood to generate the degree of serious problems which cannot be neglected for keeping discipline and order of the prison." Moreover, the restriction should not exceed necessary and reasonable limits to prevent such problems. The Court, thus narrowly limiting the discretion of prison authority, could manage to uphold the constitutionality of the Prison Act.

The other situation is presented in the Custom Bureau Inspection Case. ${ }^{56)}$ As stated above, the Custom Standard Act prohibits the importation of materials which "disturb social morality," thus depriving the public of the right to receive certain information from abroad. Yet, the Court rejected the constitutional attack against this prohibition.

54) The decision of September 16, 1988, Osaka High Court, Hanrei Jihou vol. 1305, at 70; the decision of February 19, 1990, Okayama District Court, Hanrei Times vol. 730, at 74; the decision of February 20, 1990, Kyoto District Court, Hanrei Times vol. 737, at 97.

55) The judgment of June 22, 1983, Supreme Court, grand bench, Minshu vol. 37, no. 5, at 793.

56) The judgment of Dec. 12, 1984, Supreme Court, grand bench, Minshu vol. 38, no. 12, at 1308. 
The Court construed the word "social morality" to mean sexual morality, thus limiting the coverage of prohibition to obscene materials. Since the publication of obscene materials can be prohibited, the Court could then conclude, its importation can also be constitutionally prohibited.

\section{6-3. Restrictions on the Right to Gather Information}

There is no direct statutory restrictions on the right to gather information. Yet one example of such restriction can be found in the prohibition of advocacy of illegal disclosure of official secret by the public officials in Sec. 111 of the National Public Workers Act. In the Nishiyama Case, ${ }^{57)}$ a newspaper reporter Nishiyama was prosecuted for asking his girlfriend, a public worker at the Ministry of Foreign Affairs, to bring to him a secret document showing the negotiation process between Japan and the United States concerning the return of Okinawa and was charged with a violation of Sec. 111. He attacked his conviction as an infringement of his right to gather information protected by the Constitution.

Three questions were raised: first, whether the document involved the "official secret," second, whether the prohibition of advocacy of illegal disclosure of official secret can be applied to newspaper reporter, and third, whether it is constitutional to punish newspaper reporter for his news-gathering activity.

"To decide whether the information falls within 'official secret' protected by the National Public Workers Act," the Court first held, "the court should look not only whether the information is formally classified but also whether its substance is worth for protection." And it ultimately held that the document involved was "official secret." The Court then held that the prohibition on advocacy of illegal disclosure of official secret could be applied to news-gathering activity of a reporter. The Court acknowledged that such an activity should be accorded ample respect in light of the underlying spirit of Art. 21. It thus accorded immunity to a reporter "if his activity was conducted for reporting purpose and its method was permissible in light of the prevailing social consciousness viewed against the overall legal order." In this case, however, the defendant reporter approached his girlfriend solely for the purpose of obtaining the secret document and dumped her after he had received it. His conduct, the Court thus concluded, is against social consciousness and cannot be given immunity.

57) The decision of May 31, 1978, Supreme Court, 1st petty bench, Keishu vol. 32, no. 3, at 457. 


\section{6-4. Threat to the Future Information Gathering Activity}

Some governmental acts tend to have intimidating effects on future news-gathering activity even though they do not directly restrict news-gathering activity per se.

One such governmental act is the forced disclosure of news sources. In the Ishii Case, ${ }^{58)}$ the Court refused to acknowledge a newsmen's privilege from obligation to testify in the criminal trial. This decision was handed down when the Court did not know the right to gather information. It thus held that Art. 21 protected only the right to free speech and did not reach to news-gathering activities at all.

The second such governmental act is a subpoena order against mass media. This issue was presented in the Hakata Station TV Film Subpoena Case, discussed above. ${ }^{59)}$ In this case, the Court acknowledged for the first time that the right of the TV stations to gather news should be given ample respect in light of the underlying spirit of Art. 21. The Court then employed the ad hoc interest balancing test to decide the constitutionality of the subpoena order and upheld it.

Third such case was presented in the Nippon TV Film Seizure Case. ${ }^{60)}$ In 1989, Japan was swept with the so-called Recruit scandal. The Recruit Co., an information giant, sought to bribe the government officials and politicians. When an opposition Representative Narazaki tried to inquire about the scandal in the House, chief secretary of the company even tried to bribe him. Representative Narazaki invited the TV clues of the Nippon TV to his house and videotaped the scene of bribery. The Nippon TV broadcast some portions of the tapes. Thereafter Narazaki filed a criminal complaint. The Special Bureau of District Prosecutors' Office arrested the chief secretary for bribery and, in order to bolster its case against him, seized with the court warrant all original tapes the Nippon TV had videotaped, including unedited and unbroadcast portions. The Court rejected the appeal from the Nippon TV. It applied the same interest balancing test delineated in its Hakata Station TV Film Subpoena Case and held the seizure of videotapes involved constitutional.

The Court also applied the same interest balancing test to uphold seizure of videotapes by the police officers in the TBS Videotape Seizure Case. ${ }^{61)}$ In this case, reporters of the TBS videotaped scenes of violent collections of debts by the gangsters and the police seized all videotapes as evidence for criminal prosecution. The Court admitted the importance of these tapes as evidence and discounted the possible threat

58) The judgment of August 6, 1952, Supreme Court, grand bench, Keishu vol. 6, no. 8, at 974.

59) The decision of Nov. 26, 1969, Supreme Court, grand bench, Keishu vol. 23, no. 11, at 1490.

60) The decision of Jan. 30, 1989, Supreme Court, 2nd petty bench, Keishu vol. 43 no. 1, at 19.

61) The decision of July 10, 1990, Supreme Court. 2nd petty bench, Asahisinbun July 10, 1990. 
to future news-gathering activities of the media reporters by emphasizing the fact the reporters intentionally continued to videotape the scene of violence with the consent of gangsters.

\section{6-5. The Right to Demand Disclosure of Governmental Information}

Even though leading commentators acknowledge the right of the public to demand disclosure of governmental information, no Freedom of Information Act is enacted thus far. Yet an increasing number of municipalities has enacted Freedom of Information Ordinances and guarantees to its residents the right to demand disclosure of administrative information of each municipality.

In absence of such statute or ordinance, it is generally thought that the public cannot file a suit demanding the Government to disclose specific information. This does not apply, however, when the Constitution itself obliges the Government to disclose its information.

One such example is an obligation to open trial imposed by Art. 82 of the Constitution. Since open trial is constitutionally mandated, one should be allowed to file a suit under Article 21 if the court closes the courtroom or otherwise restricts access. That obligation, however, does not force the presiding judge, as the Court held in the Hokkai Times Case, ${ }^{62)}$ to allow utterly free photographing in the courtroom. If the reporter disturbed the order of the courtroom in attempt to take picture of the defendant ignoring the judge's instruction, the Court concluded, the presiding judge could punish him.

When a presiding judge refused to allow the public to take note inside the courtroom, however, the Court showed a different attitude. In the Courtroom NoteTaking Case, ${ }^{63)}$ the Court acknowledged that note-taking in the courtroom should be accorded ample respect in light of the underlying spirit of Art. 21 and held that no general permit system should be established. It would be thus reasonable to require advance permit and deny permit only when there is specific likelihood that fair and efficient management of the court proceedings become unmaintainable.

\section{6-6. The Right of Access to Mass Media}

It is important for the ordinary public to receive various information. But as mass media have come to be highly concentrated, it has become extremely difficult for the ordinary public to get access to mass media. The public is deprived of any meaningful opportunity to speak before the audience. Free marketplace of ideas, so essential as a

62) The judgment of Feb. 17, 1958, Supreme Court, grand bench, Keishu vol. 12, no. 2, at 253.

63) The judgment of March 8, 1989, Supreme Court, grand bench, Minshu vol. 43, no. 2, at 89. 
foundation for free speech, then becomes merely a myth. Against this background, some people have come to assert the right of access to mass media.

The Court first confronted this issue in the Sankei Newspaper Case. ${ }^{64)}$ In this case, the Sankei Newspaper published an opinion ad prepared by the Liberal Democratic Party which criticized and ridiculed the Japan Communist Party's policy. The Japan Communist Party then requested the Paper to provide free space for rejoinder and, when its request was denied, filed a suit alleging the infringement of its right of free speech guaranteed by the Constitution. The Court rejected the suit, however, since the Sankei Newspaper is a private enterprise and is not subject to constitutional restriction. ${ }^{65)}$

\section{CONCLUSION}

Is freedom of expression sufficiently protected in Japan? This is a hard question and answer will naturally differ depending upon one's standpoint. As I have examined in this paper, freedom of expression is severely regulated by statutes and the Court has constantly upheld these regulations. No Court decision has ever invalidated any statute restricting freedom of expression. Some commentators notwithstanding, ${ }^{66)}$ I myself cannot say therefore that freedom of expression is sufficiently protected against the governmental infringement in Japan. ${ }^{67)}$

Turning our eyes from governmental restrictions to restrictions in private life, freedom of expression is threatened by private infringements as well as more subtle intimidation in many respects. Moreover, incidents of self-censorship in mass media are not rare. Japanese mass media often lacks appreciation of the significance of freedom of expression. And even terrorism against the press is not so unusual. It is still fresh in memory of many that Mayor Motoshima of the Nagasaki City who said in public that the last Emperor bore responsibility for the World War II was shot and wounded by a right-wing terrorist. It seems to be a far cry from situation where everyone is free to say whatever he or she believes. And the Diet and public authorities have been reluctant to protect such freedom of expression against private infringements.

64) The judgment of April 24, 1987, Supreme Court, 2nd petty bench, Minshu vol. 41, no. 3, at 490.

65) Since the Court found the Sankei Newspaper not liable for defamation, it refused to decide whether the right of reply can be inferred from the Civil Law.

66) See, e.g., L. Beer, supra note 1.

67) See also Kamiya, Freedom of Expression, in Kyoto American Studies Summer Seminar Specialists Conference 91 (1987) 
It is therefore an inescapable conclusion of this paper that the protection of freedom of expression is not still sufficient in Japan. Not sufficient, for now. And it is sincerely hoped that the Court will give due respect to freedom of expression in the future. 